\title{
Numerical age of the planktonic foraminiferal zonal boundary between N.15 and N.16 in the mid-latitude northwest Pacific region
}

\author{
Hiroki Hayashi ${ }^{1}$ and Masaki Takahashi ${ }^{2}$
}

Hiroki Hayashi and Masaki Takahashi (2008) Numerical age of the planktonic foraminiferal zonal boundary between N.15 and N.16 in the mid-latitude northwest Pacific region. Bull. Geol. Surv. Japan, vol. 59, (7/8), 415-422, 6 figs, 1 table.

\begin{abstract}
The first occurrence of the planktonic foraminiferal species Neogloboquadrina acostaensis, which defines the zonal boundary between zones N.15 and N.16, was precisely determined just above the KT-1 Tuff in the lower part of the Kubota Formation in the Tanagura area, Northeast Japan. According to radiometric ages of the KT-1 Tuff, this biohorizon is estimated at 10.6 Ma. Compiling deep-sea drilling data demonstrates that the biohorizon as synchronous at least in the mid-latitudes.
\end{abstract}

Keywords: biostratigraphy, planktonic foraminifera, upper Miocene, Kubota Formation, Northeast Japan

\section{Introduction}

The geologic timescale is one of the most important frameworks for discovering Earth history. When we construct a geologic timescale, we tie many chronostratigraphic data such as that from biostratigraphy, magnetostratigraphy, stable isotope stratigraphy, and so on, to chronometric data, including radioisotope dating, seafloor spreading interpolation and astronomical tuning methods. For refining a geologic timescale, each component of those should be critically tested and updated by new data.

A new geologic timescale (GTS2004; Lourens et al., 2004) has been recently published. The new timescale is constructed by astronomically-tuned biostratigraphy throughout the Neogene period. However, only a few sites, namely, Atlantic ODP Sites (925 and 926), Sicily (Italy, Mediterranean) and Morocco, were used in the late Miocene interval of the timescale. Therefore, we should test the diachroneity of each biohorizon in Pacific region by correlating biostratigraphic and chronometric data.

The planktonic foraminiferal species Neogloboquadrina acostaensis is one of the most famous marker species for Late Miocene. The first occurrence (FO) of N. acostaensis defines the zonal boundary between zones N.15 and N.16 of Blow (1969). This biohorizon has been used for identifying the Tortonian/Serravarian boundary for a long time. In the new timescale GTS2004, the first regular occurrence (FRO) of $N$. acostaensis is proposed as an index datum of the Tortonian/Serravarian boundary (Hilgen et al., 2000; Lourens et al., 2004). However, the
FO of $N$. acostaensis has been reported as being diachronous between low and middle latitudes (e.g. Hilgen et $a l ., 2000)$. Therefore, we need to confirm the availability of this biohorizon for Pacific Neogene stratigraphy.

The Miocene Kubota Formation of the Tanagura area, northeast Japan (Fig.1) yields abundant planktonic foraminifers. In addition, this sequence is intercalated with many volcaniclastic layers, some of which have been dated by radiometric methods (Takahashi et al., $2001 \mathrm{a}, \mathrm{b})$. The FO of $N$. acostaensis is restricted in the lower part of the formation (Hayashi et al., 2002).

We examined the planktonic foraminiferal biostratigraphy of the lower part of the Kubota Formation for a precise determination of the FO of $N$. acostaensis defining the N.15/N.16 boundary. Furthermore, we demonstrate the reliability of the biohorizon for dating Neogene marine strata.

\section{Geologic setting of the Tanagura area}

Neogene sequences are distributed as a half-basin structure in the Tanagura area (Fig. 1). The tectonic deformation is very slight except for the western margin of the basin, which was deformed by Miocene tectonic activity along the Tanagura Tectonic Line.

Neogene sequences in the Tanagura area are divided into three formations: the Akasaka, Kubota and Nikogi Formations, in ascending order (Fig. 2). These formations unconformably cover basement rocks belonging to the Abukuma and Yamizo belts. The Akasaka Formation is mainly composed of medium-grained sandstone with a basal conglomerate. The Kubota Formation conformably

${ }^{1}$ Department of Geoscience, Interdisciplinary Faculty of Science and Engineering, Shimane University, 1060, Nishikawatsucho, Matsue City, Shimane 690-8504, Japan. Tel: +81-852-32-6463; Fax: +81-852-32-6469; E-mail: hayashi@riko.shimane-u.ac.jp ${ }^{2}$ Institute of Geology and Geoinformation, GSJ/AIST. Tel: +81-298-61-3931; Fax: +81-298-61-3742; E-mail: msk.takahashi@aist.go.jp 


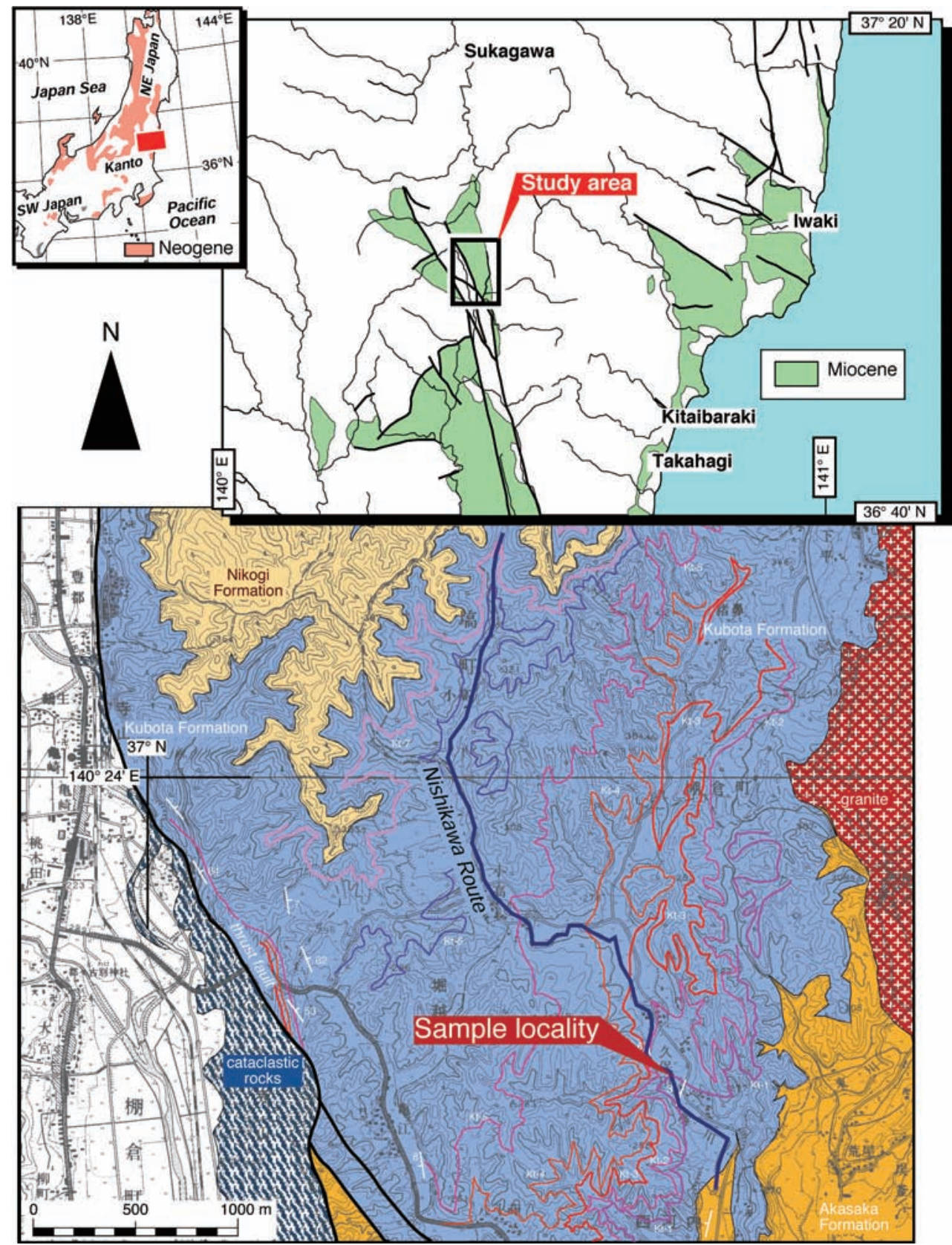

Fig. 1 Sample locality on Geologic map of the Tanagura area (modified after Shimamoto et al., 1998 and Hayashi et al., 2002). Topographic maps "Tanagura" and "Hanawa", 1:25000 in scale published by the Geographical Survey Institute of Japan.

covers the Akasaka Formation and consists of silty finegrained sandstone. This formation yields abundant marine fossils including mollusks, foraminifers, diatoms, and so on. The Nikogi Formation unconformably overlays the Kubota Formation and mainly consists of tuffaceous sandstone with a thick basal conglomerate.

The Akasaka and Kubota formations yield Shiobaratype fauna (Iwasaki, 1970; Chinzei, 1986), which is one of typical Japanese Miocene molluscan faunas. In addition, the Kubota Formation yields abundant microfossils. Aita (1988) is the first to report planktonic foraminifers from the Kubota Formation. Subsequently, Taketani and Aita (1991) studied the radiolarian biostratigraphy of the Kubota Formation. Shimamoto et al. (1998) examined planktonic foraminifera, calcareous nannofossils and radiolarians of the Kubota Formation. More recently, Hayashi et al. (2002) re-examined its planktonic foraminiferal biostratigraphy and Yanagisawa et al. (2003) conducted detailed diatom biostratigraphy of the Kubota Formation. According to those previous studies, the Kubota Formation corresponds to planktonic foraminiferal zone N.16 of Blow (1969), calcareous nan- 


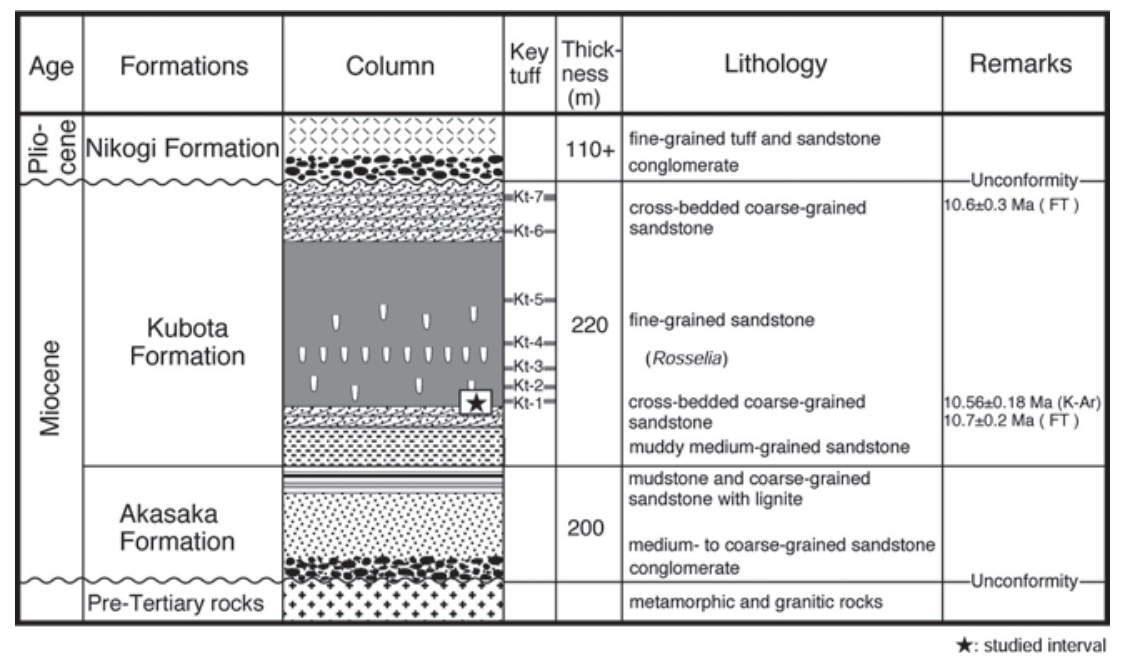

Fig. 2 Schematic geologic column of the Neogene sequences in the Tanagura area.

nofossil zones CN5b to CN7b of Okada and Bukry (1980), diatom zone NPD6 of Yanagisawa and Akiba (1998) and the radiolarian Lychnocanoma magnacornuta Zone of Motoyama and Maruyama (1996). In addition, radiometric ages have been obtained from two tuff layers, namely, KT-1 and KT-7 Tuffs (Takahashi et al., 2001a, b) (Fig. 2).

\section{Material and method}

Based on previous studies (Shimamoto et al., 1998; Hayashi et al., 2002), we presumed that the FO of $N$. acostaensis would be located around the KT-1 Tuff in the lower part of the Kubota Formation. In order to determine the precise position of the biohorizon, we collected eleven sandstone samples around the KT-1 Tuff at an interval of 0.2-1 m (Fig. 3). Rock samples (80 grams of dry weight) were disaggregated using the sodium sulfate solution and naphtha methods, and wetsieved over a 250 -mesh (63 micrometers opening). The residue was oven-dried and divided with a sample splitter. Planktonic foraminifers were picked from fractions coarser than 125 micrometers. SEM microphotographs of important species were taken by a scanning electron microscope (JSM-T220A; JEOL Co. Ltd., Tokyo, Japan).

\section{Result}

Thirty-four planktonic foraminiferal taxa from nine samples were detected (Table 1; Fig. 3). Two samples above key bed Kt-1, namely, NK7.81 and NK7.83, contain no foraminiferal fossils. The fossil preservation was generally poor, owing to the dissolution of shell surface structures and the accretion of sand grains. The maximum value for the planktonic foraminiferal number was observed at the sample NK7.8 (369 individuals / g).
Neogloboquadrina acostaensis successively occurs from sample NK7.85 and upward. Globorotaloides falconarae is found in sample NK7.88. Three biohorizons are detected in this interval; the FO and FRO of $N$. acostaensis is recognized between samples NK7.8 and NK7.85. The FO of G. falconarae is placed below sample NK7.88.

\section{Discussion}

The previous study has detected the FOs of $N$. acostaensis and G. falconarae in the lower part of the Kubota Formation (Hayashi et al., 2002). In the present study, we determined detailed positions for these biohorizons.

The FO and FRO of $N$. acostaensis are placed between samples NK7.85 and NK7.8. The sample NK7.8 is only 8 $\mathrm{cm}$ below the KT-1 Tuff, in turn the sample NK7.85 is 90 $\mathrm{cm}$ above the tuff. We consider that the FO and FRO of N. acostaensis in the Kubota Formation should be located just above the KT-1 Tuff.

The K-Ar and fission track (FT) ages of the KT-1 Tuff were determined as $10.56 \pm 0.18 \mathrm{Ma}$ and $10.7 \pm 0.2 \mathrm{Ma}$ (error in 1 sigma), respectively (Takahashi et al., 2001a). In addition, key tuff KT-7, about $170 \mathrm{~m}$ upward of the Kt-1 Tuff, was dated as $10.6 \pm 0.3 \mathrm{Ma}$ (error in 1 sigma) by the FT method (Takahashi et al., 2001b). These radiometric ages indicate a high sedimentation rate for the Kubota Formation. Accordingly, we consider that the numerical ages of the FO and FRO of $N$. acostaensis in the Tanagura area are given by the radiometric age of the KT-1 Tuff (about 10.6 Ma). This age corresponds to the middle part of geomagnetic subchron $\mathrm{C} 5 \mathrm{n} .2 \mathrm{n}$ of both the CK95 and GTS2004 timescales (Fig. 4). The difference between the numerical ages of C5n.2n in CK95 and GTS2004 is less than 0.1 Ma. Therefore, it is hard to determine which timescale is more concordant with the 


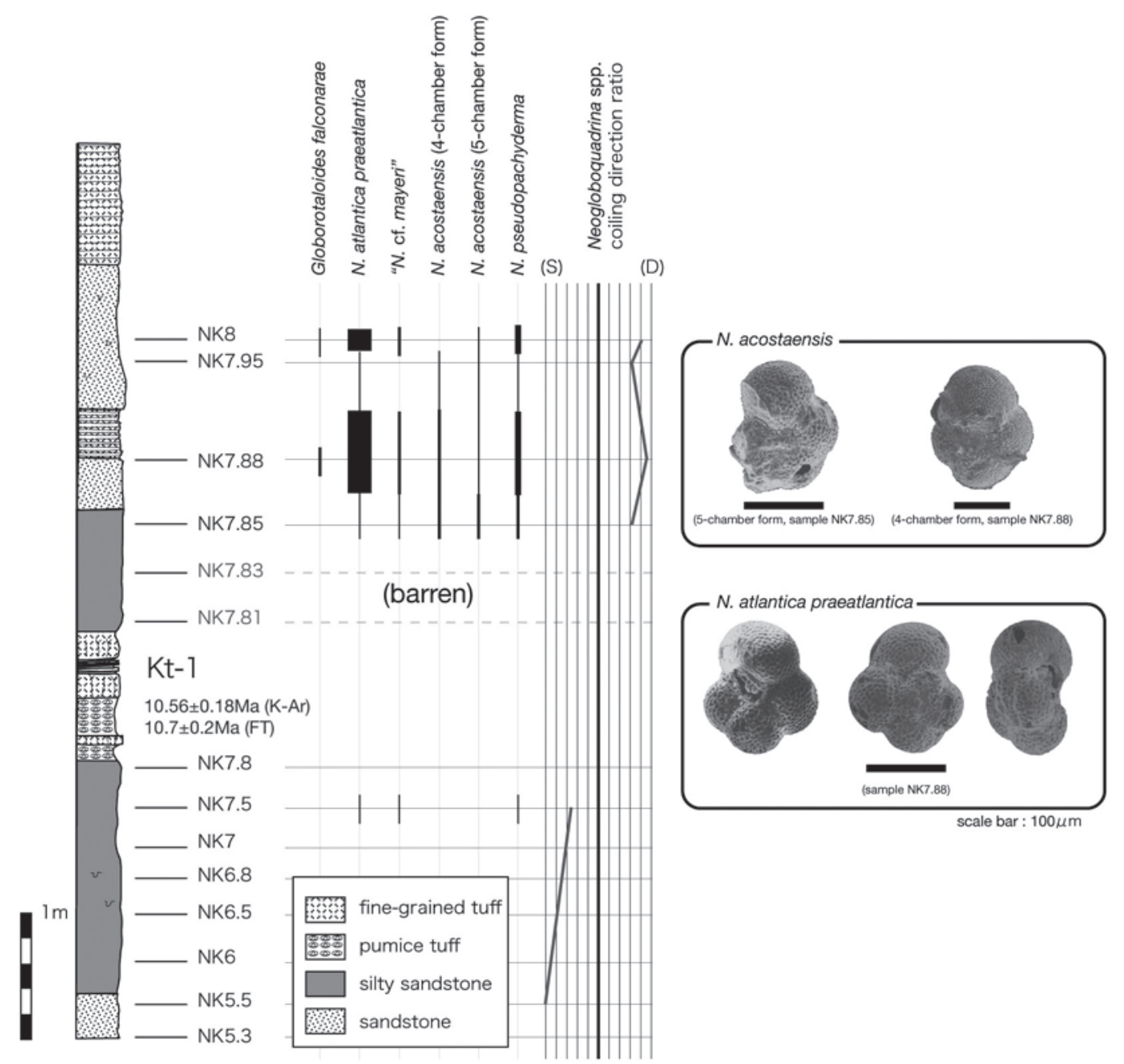

Fig. 3 Stratigraphic distribution of selected species in the lower part of the Kubota Formation. Samples in bold characters were examined in the present study, whereas others were examined by Hayashi et al. (2002).

present data.

In previous studies of deep sea cores, the FO of $N$. acostaensis has been calibrated to the lower part of subchron C5n.2n in the middle-latitude regions of the North Atlantic and the South Pacific (DSDP Sites 563, 588 and 608; compiled by Berggren et al., 1995) (Fig. 5). Considering the analytical error for radiometric ages of the KT-1 Tuff, the geomagnetic correlation of Berggren et al. (1995) is concordant with the present study.

Astronomical calibration of biohorizons has been conducted for Miocene sedimentary sequences in Sicily, in the Mediterranean (Hilgen et al., 2000; Sprovieri et al., 2002). According to these results, the FO and FRO of $N$. acostaensis are numerically dated to $11.80 \mathrm{Ma}$ and $10.554 \mathrm{Ma}$, respectively (Sprovieri et al., 2002). The former age is significantly older than Pacific and Atlantic ages proposed by Berggren et al. (1995) and in the present study. On the other hand, the latter age shows good agreement with the present study. The inconsistency could result from dispersal of this species from the high- latitude North Atlantic to other areas (Zachariasse and Aubry, 1994). We point out that the FO of N. acostaensis in DSDP Sites 588 (Jenkins and Srinivasan, 1986) and 608 (Weaver, 1987) may correspond to the FRO, like the Tanagura area. Consequently, the FO of $N$. acostaensis might be globally synchronous in mid-latitude regions such as the North Atlantic, South Pacific and Northwest Pacific.

Astronomical calibration was also been conducted at equatorial Atlantic ODP Sites 925 and 926 (compiled by Lourens et al., 2004). At those sites, the FO of $N$. acostaensis was calculated as $9.83 \mathrm{Ma}$ and located in subchron C5n.1n of both CK95 and GTS2004. This age is about $1 \mathrm{Ma}$ younger than in mid-latitude regions. As previously reported, the FO of $N$. acostaensis is diachronous between low-latitudes and mid-latitudes (Hilgen et al., 2000; Turco et al., 2002). However, the Neogene magneto-biostratigraphic timescale of GTS2004 (Lourens et al., 2004, Fig. 21.1) is based only on low-latitude ages (Fig. 4). For mid-latitude Miocene sequences, 
Table 1 Planktonic foraminifers of the lower part of the Kubota Formation. Samples displayed by bold characters are examined in the present study. Others are quoted from Hayashi et al. (2002).

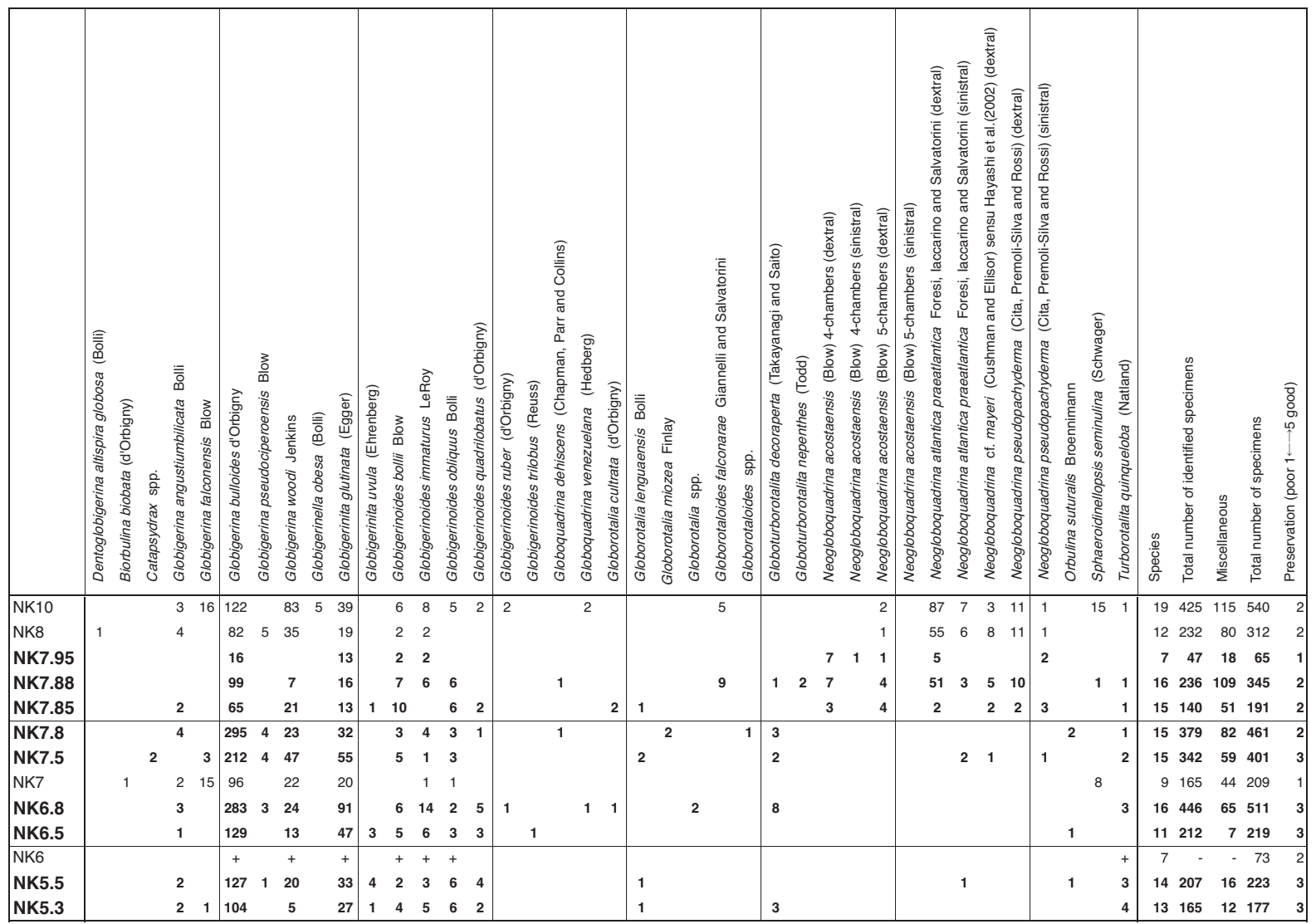

we propose that the magneto-biostratigraphic relationship of Berggren et al. (1995) is more suitable than that of GTS2004.

\section{Conclusion}

Detailed planktonic foraminiferal sampling was conducted on the lower part of the Kubota Formation in the Tanagura area, Northeast Japan, to precisely determine the FO of $N$. acostaensis and thus define the zonal boundary between zones N.15 and N.16 of Blow (1969). The FO and FRO of $N$. acostaensis are just above the KT-1 Tuff that has been dated at $10.56 \pm 0.18 \mathrm{Ma}$ by the K-Ar method and 10.7 $\pm 0.2 \mathrm{Ma}$ by the FT method. These ages suggest that the FO and FRO of $N$. acostaensis in the Tanagura area are essentially equal to $10.6 \mathrm{Ma}$. This numerical age corresponds to geomagnetic subchron C $5 n .2 n$ on the basis of both standard timescales for CK95 and GTS2004. This magneto-biostratigraphic correlation is generally concordant with previous studies based on mid-latitude deep-sea sites. We conclude that the FO of $N$. acostaensis has good potential for dating marine strata in mid-latitude regions.

\section{Taxonomic notes}

Genus Neogloboquadrina Bandy, Frerichs and Vincent, 1967

Neogloboquadrina acostaensis (Blow), 1959. Globorotalia acostaensis Blow, 1959 pl. 17, figs. 106a-c. Remarks: Twenty-seven specimens were detected in the present samples. This species is characterized by having a strongly lobulate equatorial periphery and low slit-like aperture with a distinct lip. Most individuals in the Tanagura area are dextral-coiled. In the Mediterranean, dextral coiling individuals are dominant in the interval from 11.178 to $10.011 \mathrm{Ma}$ (Hilgen et al., 2000).

Neogloboquadrina atlantica praeatlantica Foresi, Iaccarino and Salvatorini, 2002.

Neogloboquadrina atlantica praeatlantica Foresi, Iaccarino and Salvatorini, 2002 pl.1, figs. 1-13; pl.2, figs. 1-13.

Neogloboquadrina cf. pachyderma (Ehrenberg).Aita et al., 1999, p. 105, pl. 6, figs. 2a-c.

Neogloboquadrina cf. continuosa (Blow). Hayashi et al., 2002, fig. 5, 5a-c, 6a-c; Hayashi and Takahashi, 2004, fig 3, 3a-c.

Neogloboquadrina atlantica (Berggren) (small-sized). 


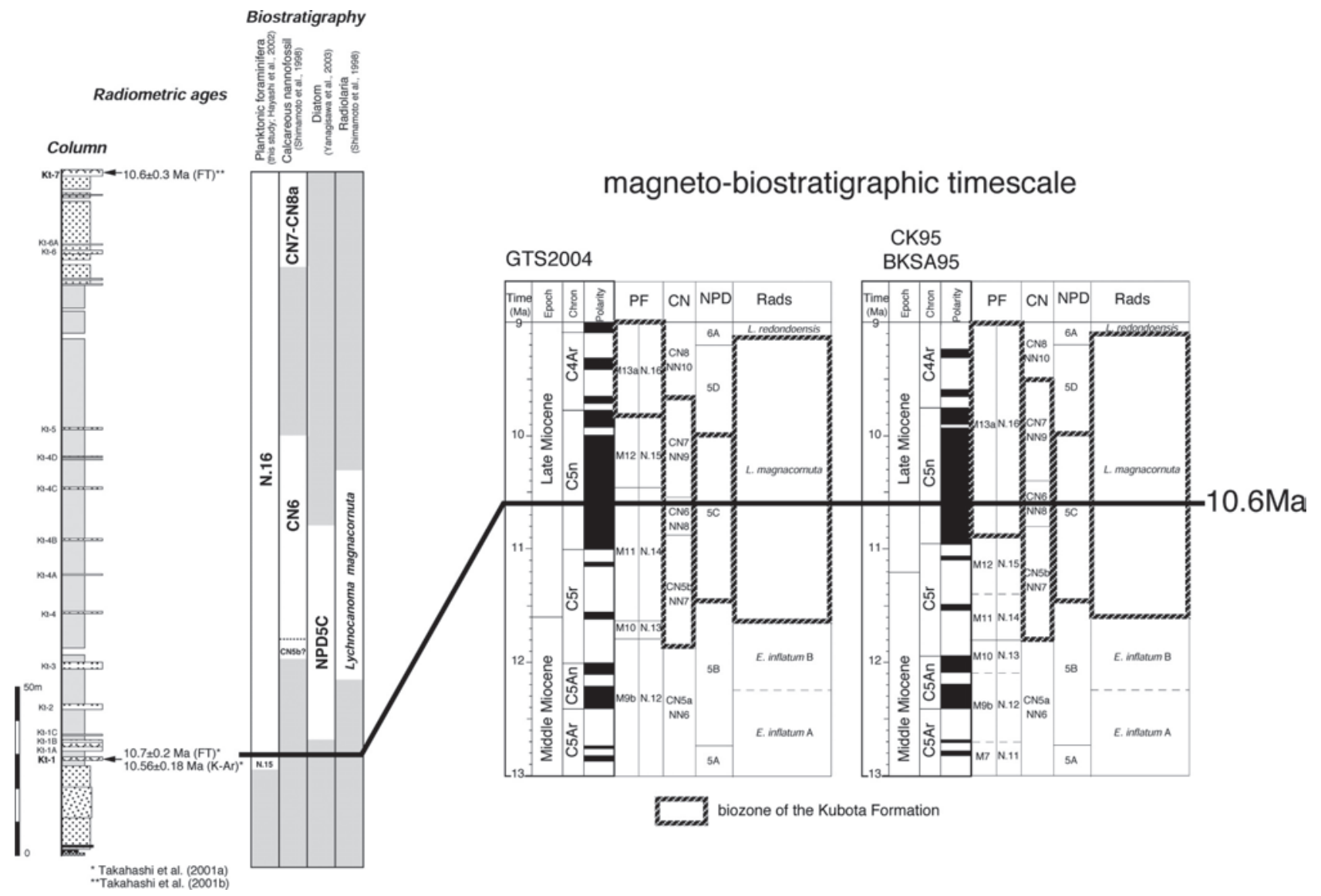

Fig. 4 Correlation of two timescales (CK95 and GTS2004) with results from the Kubota Formation. Almost all zonal correlations are concordant with the results from the Kubota Formation. However, the base of planktonic foraminiferal zone N.16 in GTS2004 is an exception and is significantly discordant with the present results.

Hilgen et al., 2000, p1.2, figs. 1-4.

Remarks: More than 200 specimens were obtained. This subspecies differs from $N$. continuosa in having a widely varying position of the aperture, which is often umbilical to extraumbilical position (Hayashi et al., 2002). Foresi et al. (2002) regarded this subspecies as an ancestor of $N$. acostaensis. We consider that Neogloboquadrina cf. mayeri (Cushman and Ellisor) sensu Hayashi et al. (2002; fig. 3, 8a-c) and the present study might be an intermediate form between $N$. atlantica praeatlantica and $N$. acostaensis.

Acknowledgements: We with to express our appreciation to Kenshiro Ogasawara of Tsukuba University for giving us the opportunity to write this paper. We also thank Yukio Yanagisawa, Yuichiro Tanaka and Mahito Watanabe of GSJ for their fruitful discussions of geologic age relations. Thanks are due to Dr. Marina Verducci of the University of Siena for kindly sending specimens from Sicily of N. atlantica praeatlantica and N. acostaensis. This work is partly supported by the Special Project for Earthquake Disaster Mitigation in Urban Areas (2002-2007) sponsored by the Japanese government.

\section{References}

Aita, Y. (1988) Neogene planktonic foraminifera from the Kubota Formation, Tanagura area, northeast Honshu, Japan. Fukushima Mus. Bull., 2, 13-27. (in Japanese with English abstract)

Aita, Y., Taketani, Y., Maruyama, T., Tanaka, Y. and Ogasawara, K. (1999) Microfossil analysis and age determination of the Neogene fossil whale bearing strata in Mamurogawa Town, Yamagata Prefecture, Northeast Japan. The Research Reports of the Fossil Whale from Mamurogawa Town, Yamagata Museum, 69-105. (in Japanese with English abstract)

Bandy, O.L., Frerichs, W.E. and Vincent, E. (1967) Origin, development, and geologic significance of Neogloboquadrina Bandy, Frerichs, and Vincent, gen. nov. Contr. Cushman Found. Foram. Res., 18, 152-157.

Berggren, W. A., Kent, D. V., Swisher, C. C., III and Aubry, M. -P. (1995) A revised Cenozoic geochronology and chronostratigraphy. In Berggren, W. A., Kent, D. V., Aubry, M. -P. and Hardenbol, J., eds., Geochronology, Time Scales and Global Stratigraphic Correlation. SEPM Special Publication, 


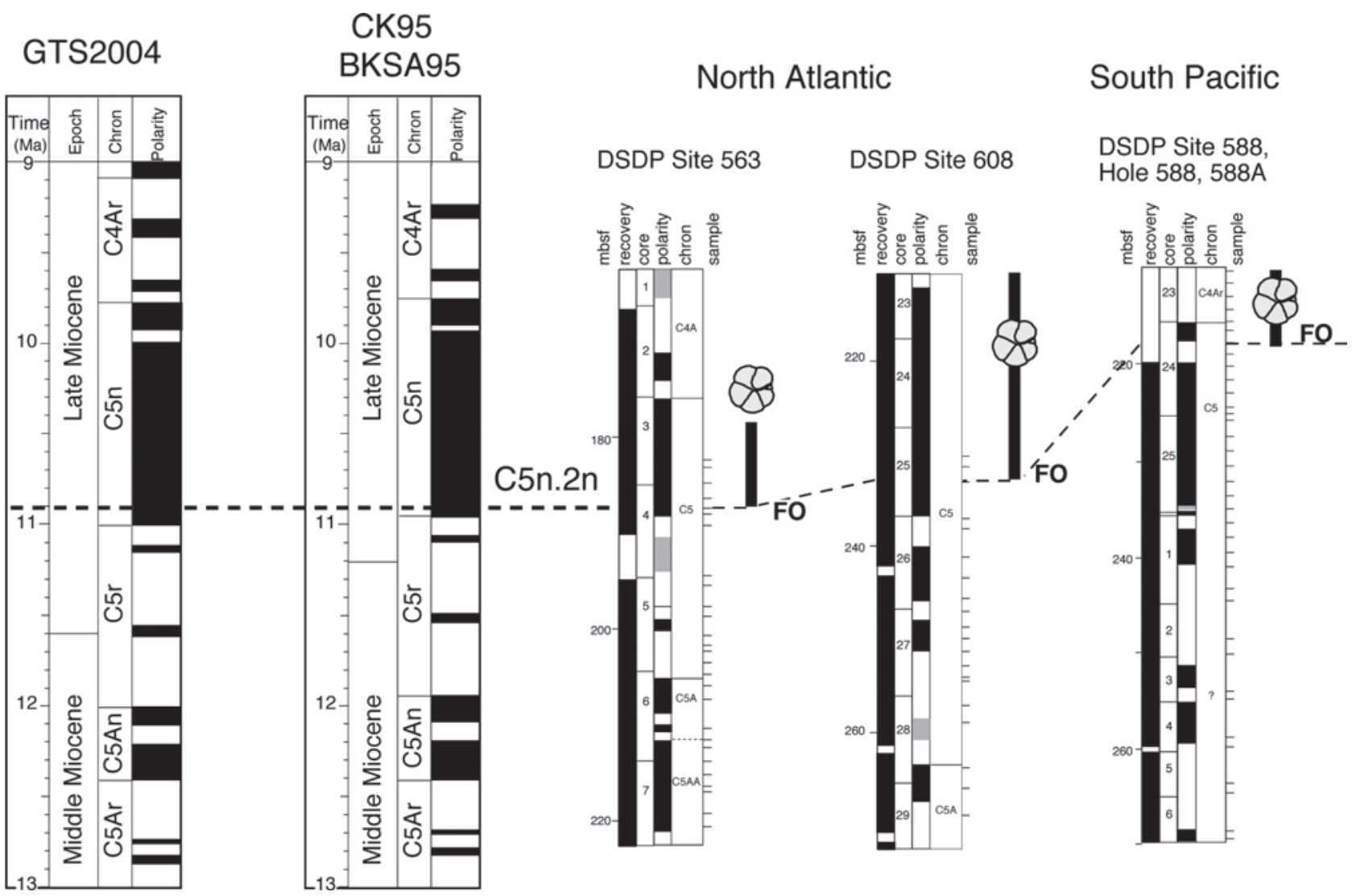

Fig. 5 Magneto-biostratigraphic correlation of the FO of Neogloboquadrina acostaensis at DSDP Sites in the North Atlantic and South Pacific.

54, 129- 212.

Blow, W. H. (1959) Age, correlation, and biostratigraphy of the Upper Tocuyo (San Lorenzo) and Pozon formations, eastern Falcon, Venezuela. Bull. Amer. Paleontol., 39, 67-251.

Blow, W. H. (1969) Late Middle Eocene to Recent planktonic foraminiferal biostratigraphy. In Brönnimann, P. and Renz, H. R., eds., Proceedings of First International Conference of Planktonic Microfossils, Geneva, 1967, 1, 199- 422.

Chinzei, K. (1986) Faunal succession and geographic distribution of Neogene molluscan faunas in Japan. Palaeontol. Soc. Japan, Spec. Publ., 29, 17-32.

Foresi, L. M., Iaccarino, S. M. and Salvatorini, G. (2002) Neogloboquadrina atlantica praeatlantica, new subspecies from late Middle Miocene. Revista Italiana di Paleontologia e Stratigrafia, 108, 325 336.

Hayashi, H., Yamaguchi, T., Takahashi, M. and Yanagisawa, Y. (2002) Planktonic foraminiferal biostratigraphy of the upper Miocene Kubota Formation in the eastern Tanagura area, northeast Japan. Bull. Geol. Surv. Japan, 53, 409-420. (in Japanese with English abstract)

Hayashi, H. and Takahashi, M. (2004) Miocene planktonic foraminiferal biostratigraphy of the upper part of the Arakawa Group in the Karasuyama area, Tochigi Prefecture, central Japan. Jour. Geol. Soc. Japan, 110, 85-92. (in Japanese with English abstract)

Hilgen, F. J., Krijgsman, W., Raffi, I., Turco, E. and Zachariasse, W. J. (2000) Integrated stratigraphy and astronomical calibration of the Serravallian/Tortonian boundary section at Monte Gibliscemi (Sicily, Italy). Mar. Micropaleontol., 38, 181-211.

Iwasaki, Y. (1970) The Shiobara-type molluscan fauna. Jour. Fac. Sci, Univ. of Tokyo, Sec. 2, 17, 351-444.

Jenkins, D. G. and Srinivasan, M. S. (1986) Cenozoic planktonic foraminifers from the equator to the subAntarctic of the southwest Pacific. In Kennett, J. P. et al., eds., Init. Rep. DSDP, 90, 795-834.

Lourens, L. J., Hilgen, F. J., Lasker, J., Shackleton, N. J. and Wilson, D. (2004) The Neogene period. In Gradstein, F. M. et al., eds., A Geologic Time Scale. Cambridge University Press, 409-440.

Motoyama, I. and Maruyama, T. (1996) Integrated radiolarian and diatom biostratigraphy of the Neogene strata in the Tsugaru Peninsula, Aomori Prefecture, northern Honshu, Japan. Jour. Geol. Soc. Japan, 102, 481-499. (in Japanese with English abstract)

Okada, H., and Bukry, D. (1980) Supplementary modification and introduction of code numbers to the low- 
latitude coccolith biostratigraphic zonation (Bukry, 1973; 1975). Mar. Micropaleontol., 5, 321- 325.

Shimamoto, M., Hayashi, H., Suzuki, N., Tanaka, Y. and Saito, T. (1998) Lithostratigraphy and microfossil biostratigraphy of Neogene sediments in the eastern Tanagura area, Fukushima Prefecture, Northeast Japan. Jour. Geol. Soc. Japan, 104, 296312. (in Japanese with English abstract)

Sprovieri, R., Bonomo, S., Caruso, A., di Stefano, A., di Stefano, E., Foresi, L. M., Iaccarino, S. M., Lirer, F., Mazzei, R. and Salvatorini, G. (2002) An integrated calcareous plankton biostratigraphic scheme and biochronology for the Mediterranean Middle Miocene. Revista Italiana di Paleontologia e Stratigrafia, 108, 337-353.

Takahashi, M., Hayashi, H., Iwano, H. and Okada, T. (2001a) K-Ar and fission track ages of the Kt-1 Tuff in the Miocene marine sequence in the Tanagura area, Northeast Japan. Jour. Japanese Assoc. Petrol. Technol., 66, 311-318.

Takahashi, M., Iwano, H., Yanagisawa, Y. and Hayashi, H. (2001b) Fission track age of the Kt-7 Tuff in the Miocene Kubota Formation in the eastern Tanagura area, Northeast Japan. Bull. Geol. Surv. Japan, 52, 291-301.

Taketani, Y. and Aita, Y. (1991) Miocene Radiolaria from the Kubota Formation, Tanagura Area, Northeast Japan. Bull. Fukushima Mus., 5, 31-51. (in Japanese with English abstract)
Turco, E., Bambini, A.M., Foresi, L., Iaccarino, S., Lirer, F., Mazzei, R. and Salvatorini, G. (2002) Middle Miocene high-resolution calcareous plankton biostratigraphy at Site 926 (Leg 154, equatorial Atlantic Ocean): palaeoecological and palaeobiogeographical implications. Geobios, Memoire special, no. 24, 257-276.

Weaver, P.P.E. (1987) Late Miocene to Recent planktonic foraminifers from the North Atlantic: Deep Sea Drilling Project Leg 94. In Ruddiman, W.F., et al., eds., Init. Rep. DSDP, 94, 703-727.

Yanagisawa, Y. and Akiba, F. (1998) Refined Neogene diatom biostratigraphy for the northwest Pacific around Japan, with an introduction of code numbers for selected diatom biohorizons. Jour. Geol. Soc. Japan, 100, 136-149.

Yanagisawa, Y., Yamaguchi, T. and Hayashi, H. (2003) Marine diatom biostratigraphy and paleoenvironment of the upper Miocene Kubota Formation in the Higashi-tanagura area, Fukushima Prefecture, northeastern Japan. Bull. Geol. Surv. Japan, 54, 29-47. (in Japanese with English abstract)

Zachariasse, W. J. and Aubry, M. P. (1994) Origin and early dispersal of Neogloboquadrina. Paleobios, 16, 68.

Received July, 15, 2008

Accepted September, 16, 2008

\title{
北西太平洋中緯度地域における浮遊性有孔虫化石帯 N.15 帯と N.16 帯境界の数値年代 \\ 林 広樹・高橋雅紀
}

\author{
要 旨
}

福島県棚倉地域の久保田層下部について詳細な浮遊性有孔虫生層序を検討した結果, 化石帯 N.15 帯と N.16 帯の境界 を定義する生層準 Neogloboquadrina acostaensis の初産出を凝灰岩鍵層 KT-1の直上に認めた。この凝灰岩鍵層の放射年代 に基づき，本地域における N. acostaensis の初産出年代を $10.6 \mathrm{Ma}$ と見積もった。これまでに報告されている深海掘削の データから判断すると, この生層準は少なくとも中緯度地域では同時性を示し，年代対比に有用であると考えられる. 